\title{
GYNANDROSPOROUS SPECIES OF OEDOGONIUM BORISIANUM (LE CL.) WITTR. EX HIRN (CHLOROPHYCEAE) FROM BANGLADESH
}

\author{
Sabrina Naz ${ }^{1}$, Umma Nahar, Md. Solaiman Ali \\ and Shah Md. Golam Gousul Azam \\ Department of Botany, University of Rajshahi, Rajshahi-6205, Bangladesh
}

Key words: Oedogonium borisianum, Gynandrosporous sp., Green alga, Bangladesh

\begin{abstract}
Gynandrosporus species of Oedogonium borisianum (Le Cl.) Wiltr. ex Hirn not reported earlier from Bangladesh has been described and illustrated.

Recently 72 taxa of Oedogonium have been complied from Bangladesh (Ahmed et al. 2008). Islam et al. (1980) described idioandrosporus form of O. borisianum (Le Cl.) Wittr. ex Hirn from Dubalhati Beel of Naogaon, Bangladesh. Gonzalves (1981) mentioned that this species could be gynandrosporus or idioandrosporus. During the survey of Oedogonium spp. from Rajshahi district (Naz et al. 2009), the authors come across the gynandrosporus sp. of $O$. borisianum which is described and illustrated in the present account.
\end{abstract}

Oedogonium borisianum (Le Cl.) Wittr. ex Hirn

(Figs 1-2)

(Gonzalves 1981, 396, Pl. 9, Fig. 292A)

Plants dioceious, gynandrosporous. Vegetative cells cylindrical, 46-73 $\mu \mathrm{m}$ long, 11-13.2 $\mu \mathrm{m}$ in diameter, basal cell elongate. Suffultory cell inflated, $48 \mu \mathrm{m}$ long, $38 \mu \mathrm{m}$ in diameter. Oogonium single, obovoid or ellipsoid, $43 \mu \mathrm{m}$ long, $33 \mu \mathrm{m}$ in diameter, poriferous, pore superior; oospore ovoid nearly filling the oogonium, $36 \mu \mathrm{m}$ long, $30 \mu \mathrm{m}$ in diameter, oospore wall smooth. Androsporangia seriate, on the upper part or top of the filament, up to 7 in number on the same filament bearing oogonium, $24 \mu \mathrm{m}$ long, $10 \mu \mathrm{m}$ in diameter. Dwarf male (nannandrium) somewhat curved, situated on the suffultory cells, $33 \mu \mathrm{m}$ long, $10 \mu \mathrm{m}$ in diameter.

Notes: Islam et al. (1980) described idioandrosporous sp. of this alga; dwarf male dumble shaped, straight; oogonial pore median.

Collection No. Oed. 039, 109, 115; 18.11.2001, Godagari Beel and Dharampur Beel in Godagari, Rajshahi, growing on Ipomoea aquatica Forsk., pH 7.3.

\footnotetext{
${ }^{1}$ Corresponding author: E-mail: drsabrina_naz@yahoo.com
} 


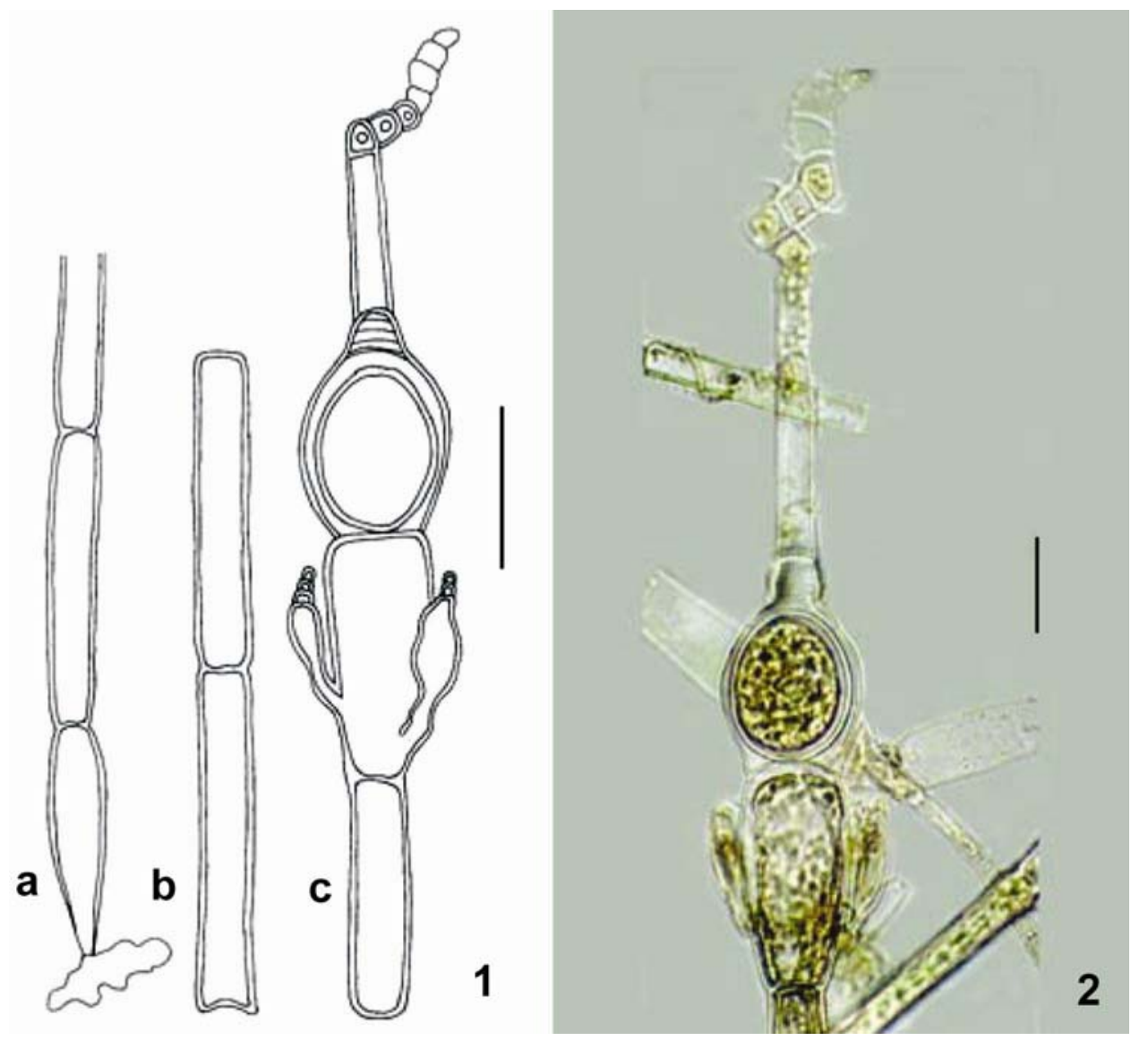

Figs 1-2. Oedogonium borisianum (Le Cl.) Wittr. ex Hirn. 1a-c. Filament with basal holdfast (a), two cells from median region of the filament (b) and oogonium, dwarf males and series of androsporangia (c). 2. A photomicrograph of the alga showing suffultory cell, nannadria, oogonium and androsporangia at the tip. Scales $=50 \mu \mathrm{m}$.

\section{References}

Ahmed Z.U., Z.N.T. Begum, M.A. Hassan, M. Khondker, S.M.H. Kabir, M. Ahmed, A.T.A. Ahmed, A.K.A. Rahman and E.U. Huq (Eds). 2008. Encyclopedia of Flora and Fauna of Bangladesh. Vol. 3. Algae, Chlorophyta (Aphanochaetaceae-Zygnemaceae). pp. 541-585. Asiatic Soc. Bangladesh, Dhaka.

Gonzalves E.A. 1981. Oedogoniales. ICAR, New Delhi. 757 pp.

Islam A.K.M.N., Anatunnesa and A.K.Y. Haroon. 1980. Hydrobiological studies in and around Naogaon, Rajshahi. Dacca Univ. Stud. B 28(2): 31-47.

Naz S., U. Nahar, M.S. Ali and S.M.G.G. Azam. 2009. New records of Oedogonium Link in Nees from Rajshahi district, Bangladesh. Bangladesh J. Bot. 38(1): 27-31. 